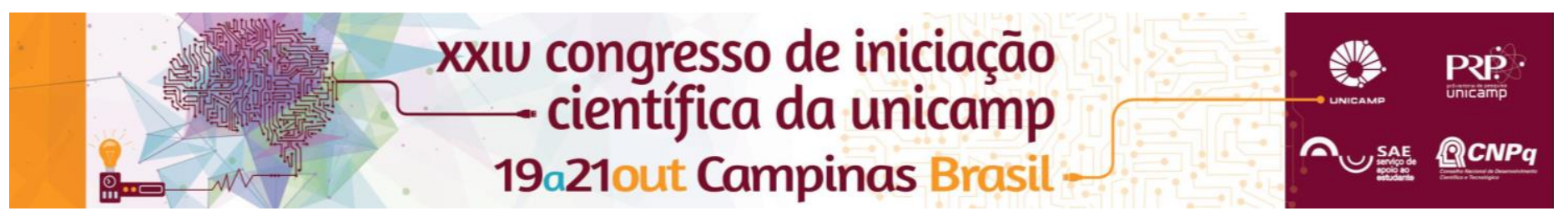

\title{
Avaliação da produção de etanol de linhagens industriais de $S$. cerevisiae frente aos diferentes hidrolisados de cana-de-açúcar
}

\author{
Vanessa S. Teixeira*, Rafaela R. Rosolen, Priscila H. Carvalho, Cláudia Steckelberg, Silvio R. Andrietta, Maria da \\ Graça S. Andrietta e Rosana Goldbeck
}

\section{Resumo}

Este trabalho tem como objetivo avaliar a produção de etanol de 06 linhagens industriais de $S$. cerevisiae frente aos diferentes hidrolisados de cana-de-açúcar (ácido, alcalino, enzimático). As hidrólises foram realizadas a fim de liberar os açúcares fermentescíveis presentes no bagaço. As fermentações foram realizadas em Erlernmeyers a 32ํㅡ, $150 \mathrm{rpm}, \mathrm{pH} 5,0$ e meio suplementado com glicose até $150 \mathrm{~g} / \mathrm{L}$. O etanol foi quantificado por cromatografia líquida de alta performace (HPLC), em cromatógrafo Varian ${ }^{\circledR}$, coluna HPX $87 \mathrm{H}$, com detector de índice de refração e fase móvel com ácido sulfúrico $5 \mathrm{mM}$.

\section{Palavras-chave}

S. cerevisiae, Etanol, Hidrolisado de bagaço de cana-de-açúcar.

\section{Introdução}

A levedura $S$. cerevisiae vem sendo empregada na indústria sucroalcooleira há décadas, por ser uma excelente fermentadora de bioetanol, além de ser tolerante ao seu produto de fermentação e tolerar bem $\mathrm{pHs}$ baixos (pH 3-7) (Jeffries, 2006). Porém essa levedura não é capaz de metabolizar carboidratos complexos, de modo que é preciso realizar previamente uma hidrólise e gerar monômeros de glicose a partir de celulose.

Nos últimos anos, estudos tecnológicos na área de fermentação se concentram na busca e desenvolvimento de micro-organismos mais robustos, que consigam produzir bioetanol a partir dessa biomassa residual com maior eficiência (Almeida et al., 2009).

Em face disto, este trabalho teve como objetivo avaliar a produção de etanol de 06 linhagens industriais de $S$. cerevisiae frente aos diferentes hidrolisados de canade-açúcar (ácido, alcalino, enzimático).

\section{Resultados e Discussão}

Os hidrolisados gerados na hidrólise ácida, alcalina e enzimática foram caracterizados e submetidos a fermentação. Quantificou-se a produção de etanol por meio de cromotografia líquida de alta performace (Figuras 1, 2 e 3).

Foram estudadas 06 linhagens de leveduras: CAT-1 (Usina Catanduva); PE-2 (Usina da Pedra); FT858 (Usina da Pedra - Fermentec); SM (Usina São Manoel); SA (Usina Santa Adélia), NAD (Usina Nardini).

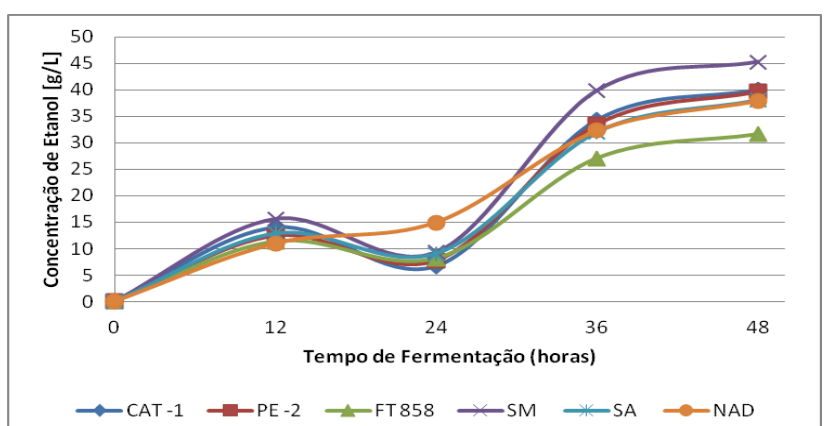

Figura 1. Avaliação da produção de etanol pelas 06 linhagens de $S$. cerevisiae quando empregado 0 hidrolisado ácido.

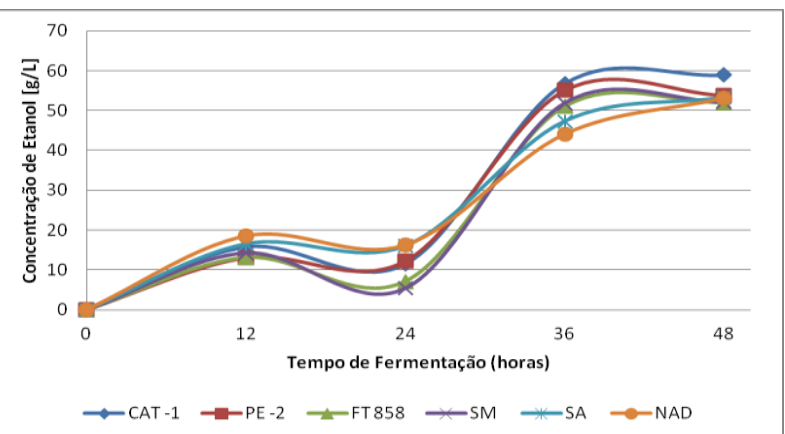

Figura 2. Avaliação da produção de etanol pelas 06 linhagens de $S$. cerevisiae quando empregado 0 hidrolisado alcalino.

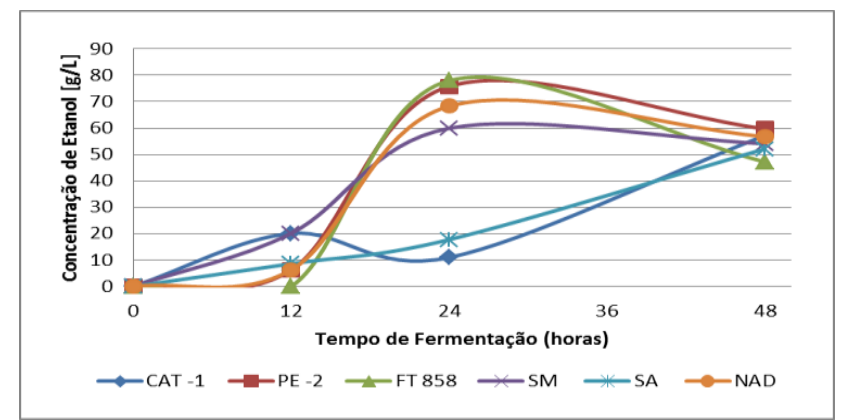

Figura 3. Avaliação da produção de etanol pelas 06 linhagens de $S$. cerevisiae quando empregado 0 hidrolisado enzimático.

\section{Conclusões}

Dentre os processos de hidrólise estudados pode-se observar que para todas as linhagens os melhores resultados de produção de etanol após 48h de fermentação foram à partir dos hidrolisados alcalino e enzimático, sendo que a linhagem CAT-1 produziu $58,92 \mathrm{~g} / \mathrm{L}$ e $57,12 \mathrm{~g} / \mathrm{L}$ de etanol à partir do hidrolisado alcalino e enzimático respectivamente.

Agradecimentos

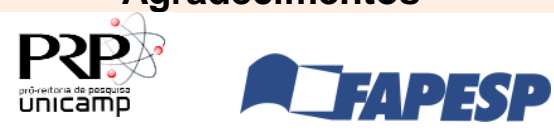

\footnotetext{
${ }^{1}$ Almeida, J.R.M., Karhumaa, K., Bengtsson, O., Gorwa-Grauslund, M.F. Bioresour. Technol. 2009, 100, 3674-3677.

${ }^{2}$ Jeffries, T.W. Curr. Opin. Biotechnol., 2006,17, 320-32.
} 